\title{
NILAI-NILAI KEARIFAN LINGKUNGAN DALAM NOVEL SERIAL ANAK-ANAK MAMAK KARYA TERE LIYE (KAJIAN ECOCRITICISM)
}

\author{
Ahmad Nizarul Fanani \\ SMA Hidayatus Salam Lowayu Dukun Gresik \\ HP082152351488; pos-elnizarfanani09@gmail.com
}

\begin{abstract}
Abstrak: Penelitian ini dilatarbelakangi oleh karya sastra dilihat dari segi ekologi dan mengajak pembaca untuk selalu menjaga kelestarian lingkungan hidup dengan melestarikan nilai-nilai kearifan lingkungan hidup melalui pembacaan karya sastra. Penelitian ini bertujuan untuk mengetahui nilai-nilai kearifan lingkungan yang terdapat dalam novel serial anak-anak mamak karya Tere Liye. Penelitian ini menggunakan metode penelitian deskriptif kualitatif. Data pada penelitian ini berupa kalimat nilainilai kearifan lingkungan yang terdapat dalam novel Serial Anak-Anak Mamak karya Tere Liye yang terdiri dari empat novel yaitu novel Burlian (2009), Pukat (2010), Eliana (2011), dan Amelia (2013) kesemuanya diterbitkan oleh Republika Penerbit. Teknik pengumpulan data dalam penelitian ini adalah menggunakan teknik kepustakaan, teknik simak, dan teknik catat. Analisis datanya yaitu analisis deskripsi dan analisis isi. Hasil Penelitian antara lain nilai-nilai kearifan lingkungan berupa rasa hormat terhadap alam, Rasa kepemilikan bersama masyarakat untuk menjaga sumber daya alam, Sistem pengetahuan masyarakat setempat untuk memecahkan masalah, Teknologi tepat guna dan hemat sesuai dengan kondisi setempat, Sistem penegakan aturan-aturan adat masyarakat, dan mekanisme pemerataan hasil panen.
\end{abstract}

Kata Kunci: Ekokritik, nilai-nilai, kearifan, lingkungan.

Abstract: This research is motivated by literature in terms of ecology and invites readers to always maintain environmental sustainability by preserving the values of environmental wisdom through the reading of literary works. This study aims to determine the values of environmental wisdom contained in the novel Serial Anak-anak Mamak by Tere Liye. This research uses descriptive qualitative research method. The data in this research are sentence of the values of environmental wisdom contained in novel Serial Anak-Anak Mamak by Tere Liye which consists of four novels namely novel Burlian (2009), Pukat (2010), Eliana (2011), and Amelia (2013) all of them published by Republika Publisher. Data collection techniques in this study is to use literature techniques, techniques refer, and record techniques. Data analysis is the analysis of description and content analysis. Research results include environmental wisdom values in the form of respect for nature, a sense of common ownership of the community to maintain natural resources, local knowledge systems to solve problems, appropriate and efficient technologies in accordance with local conditions, system of law enforcement rules, and harvest distribution mechanisms.

Key Words: Ecocritic, values, wisdom, environmental. 


\section{PENDAHULUAN}

Karya sastra pada hakikatnya merupakan tanggapan seseorang (pengarang) terhadap situasi yang terjadi dalam masyarakat sekelilingnya. Selama ini sastra lebih dilihat secara antroposentris sebagai artefak budaya yang berpusat dan terpusat pada manusia. Akibat logisnya, nilai-nilai dan pesan moral sebagai substansi hakikat dalam sastra cenderung dilihat, dianggap, dan disikapi sebagai acuan standar ideal perilaku manusia dalam kehidupannya sebagai makhluk individual dan sosial, bukan sebagai makhluk biologis, lebihlebih sebagai makhluk ekologis. Pengungkapan ekokritik dianggap mampu menjelaskan bahwa sastra merupakan produk kreatif alam dimana manusia menjadi bagian yang tidak terpisahkan di dalamnya

Menurut Garrard (2004:5), Ecocriticism meliputi studi tentang hubungan antara manusia dan non manusia, sejarah manusia dan budaya yang berkaitan dengan analisis kritis tentang manusia dan lingkungannya. Ekokritisisme merupakan kajian tentang hubungan antara sastra dan lingkungan fisik. Seperti halnya kritisisme feminis mengkaji bahasa dan sastra dari perspektif kesadaran gender, ekokritisisme mengkaji sastra dengan pendekatan berbasis bumi (alam). Ekokritisisme itu sendiri dapat dibatasi sebagai studi tentang hubungan antara karya sastra dan lingkungan fisik (Sudikan, 2016:4).

Teori ekokritik bersifat multidisiplin. Di satu sisi ekokritik menggunakan teori sastra dan di sisi lain menggunakan teori ekologi. Teori sastra merupakan teori yang mulidisiplin begitu pula teori ekologi. Dalam sudut pandang teori sastra, teori ekokritik dapat dirunut datam paradigma teori mimetik yang memiliki asumsi dasar bahwa kesusastraan memiliki keterkaitan dengan kenyataan.

Kemunculan ekokritik tampaknya merupakan konsekuensi logis dari keberadaan ekologis yang makin memerlukan perhatian manusia. Selama dalam dominasi orientasi kosmosentris, teosentris, antroposentris, dan logosentris, keberadaan ekologis terlalu jauh dari pusat orientasi pemikiran dan bahkan terpinggirkan sehingga pada akhirnya terlupakan. Kondisi demikian disebabkan oleh ketidakseimbangan dominasi budaya yang terlalu eksploitatif terhadap alam. Kegiatan eksploitatif itu mendorong berdirinya industry-industri. Dunia industri yang dipelopori kaum kapitalis itu mampu menggeser kebudayaan, dan kearifan lokal sejak nenek moyang.

Keraf (2010:28) menyatakan bahwa kearifan lokal adalah semua bentuk pengetahuan, keyakinan, pemahaman atau wawasan serta adat kebiasaan atau etika yang menuntun perilaku manusia dalam kehidupan di dalam komunitas ekologis. Sikap dan perilaku khas masyarakat lokal terhadap alam sekitarnya disebut kearifan lingkungan. Kearifan lingkungan adalah sebuah kesadaran untuk menjadi bagian dari alam sehingga tercipta satu kesatuan harmoni antara manusia dengan alam (Amrih, 2008:33).

Alam telah menjadi bagian dari sastra. Ini terbukti dengan tidak sedikitnya sastrawan, khususnya dari kalangan penyair, yang menggunakan diksi hutan, laut, pohon, dan lain-lain dalam karya mereka. Namun seiring perkembangan, sastra telah banyak mengalami perubahan, begitu juga alam. Kedua elemen yang tak terpisahkan ini seakan selalu berjalan beriringan. Sastra tempo dulu adalah wajah alam masa lalu dan sastra sekarang adalah wajah alam masa kini. Sastra membutuhkan alam sebagai inspirasinya, sedang alam 
membutuhkan sastra sebagai alat konservasinya.

Salah satu karya sastra yang memanfaatkan alam sebagai latar fisik dan atau obyek penceritaannya adalah novel Serial Anak-anak Mamak karya Tere Liye. Novel ini merupakan kumpulan dari beberapa novel Burlian (2009), Pukat (2010), Eliana (2011), and Amelia (2013). Dalam novel, settingnya digambarkan di lembah bukit Provinsi Sumatra Selatan, sebuah desa yang dikelilingi oleh hutan dan sungai yang asri. Kisahnya tentang keluarga sederhana, Pak Syahdan dan Mak Nur yang membesarkan anak-anaknya dengan disiplin yang tinggi dan memberikan teladan dari perbuatannya. Empat anakanak mamak ini memiliki karakter yang berbeda-beda. Eliana yang pemberani, Pukat yang cerdas, Burlian yang cerdik dan Amelia yang serba ingin tahu (Liye, 2011:3).

Alasan peneliti mengangap pentingnya novel serial anak-anak mamak karya Tere Liye ini diteliti adalah novel serial ini mengajak pembaca untuk selalu menjaga kelestarian lingkungan hidup dengan melestarikan tradisi masyakarakat yang memuat nilai-nilai kearifan lingkungan hidup. Dari alasan tersebut, peneliti tertarik melakukan penelitian bertujuan untuk mengetahui nilai-nilai kearifan lingkungan yang terdapat dalam novel serial anak-anak mamak karya Tere Liye.

\section{METODE PENELITIAN}

Jenis penelitian ini adalah penelitian kualitatif deskriptif, dimana peneliti dihadapkan sebuah dokumen novel Serial Anak-Anak Mamak karya Tere Liye yang akan dikaji struktur novel dan perbandingan dengan teori ecocriticism. Penelitian kualitatif deskriptif adalah penelitian dimana data yang dianalisis dan hasil analisisnya berbentuk deskripsi fenomena, tidak berupa angka-angka atau koefisien tentang hubungan antar variable (Aminudin, 1990:16).

Data dalam penelitian ini yaitu berupa kalimat nilai-nilai kearifan lingkungan yang terdapat dalam novel Serial Anak-Anak Mamak karya Tere Liye. Novel serial ini terdiri dari 4 novel yaitu novel Burlian (2009), Pukat (2010), Eliana (2011), dan Amelia (2013) kesemuanya diterbitkan oleh Republika Penerbit.

Teknik pengumpulan data dalam penelitian ini adalah menggunakan teknik kepustakaan, teknik simak, dan teknik catat. Sumber data yang digunakan dalam penelitian ini adalah novel Serial AnakAnak Mamak karya Tere Liye, maka data digali dengan cara dokumentasi, membaca, menyimak kandungan atau isi yang digunakan dalam novel tersebut, kemudian dicatat data yang berhubungan atau terkait dengan nilai kearifan lingkungan. Instrumen pengumpulan data yang digunakan adalah lembar korpus data.

Teknik analisis data yang digunakan dalam penelitian ini yaitu kualitatif deskriptif dimana data yang dianalisis dan hasil analisisnya berbentuk deskripsi fenomena. Prosedur penganalisisan data menggunakan langkah sebagai berikut: (1) Membaca berkali-kali novel Serial Anak-Anak Mamak karya Tere Liye. (2) Membaca secara cermat data pada lembar korpus data. (3) Mengklasifikasikan nilai-nilai kearifan lingkungan dalam novel. (4) Menganalisis masalah nilai-nilai kearifan lingkungan yang ada dalam novel berdasarkan pendekatan teori ekologi. (5) Menyimpulkan nilai-nilai kearifan lingkungan terdapat dalam novel serial anak-anak mamak karya Tere Liye.

\section{HASIL DAN PEMBAHASAN}

Nilai-nilai kearifan lingkungan dapat diwujudkan dengan upaya 
pengelolaan sumber daya alam dan lingkungan yang juga merupakan wujud konservasi oleh masyarakat. Menurut Nababan (1995:48), prinsip-prinsip konservasi oleh masyarakat secara tradisional antara lain: rasa hormat terhadap alam, rasa kepemilikan bersama, sistem pengetahuan masyarakat setempat, teknologi tepat guna, sistem penegakkan aturan adat, dan mekanisme pemerataan hasil panen atau sumberdaya alam bersama.

\section{Rasa hormat terhadap alam}

Dalam hal ini masyarakat tradisional lebih condong memandang dirinya sebagai bagian dari alam. Dengan hal itu sehingga mendorong keselarasan (harmoni) hubungan manusia dengan alam sekitarnya. Adanya perasaan ini dikarenakan bekerjanya otak yang mencerna rangsangan dari panca indera sehingga jiwa manusia merasa menyatu dengan alam. Hal ini juga dirasakan oleh Amelia, tokoh utama dari novel Amelia Serial Anak-anak Mamak. Sebagaimana kutipan berikut.

Aku dan keluargaku tinggal di perkampungan yang indah. Persis di Lembah Bukit Barisan. Dilingkari oleh hutan lebat di bagian atasnya. Lerenglereng yang berkabut saat pagi, bagai melihat kapas sejauh mata memandang. Di bawahnya dibatasi oleh sungai besar berair jernih. Jika datang pagi-pagi, pukul enam misalnya, kalian akan melihat air sungai yang seolah menyimpan balokbalok es, mengepul mengeluarkan uap. Begitu jernih, begitu dingin. Koral dasar sungai terlihat. Ikan berlarian di sela kaki membuat geli. (T.a/001/2.1).

Dari data 001 dapat diketahui bahwa pengarang mengajak pembaca seakan-akan menikmati keasrian alam dan memandang dirinya bagian dari alam dengan dihanyutkan dalam suasana sungai yang segar dengan banyak ikan di sekitarnya. Selain sungai yang segar, pembaca juga bisa menikmati suasana ladang dan hutan yang asri pada novel yang sama. Seperti pada kutipan novel Amelia Serial Anak-anak Mamak berikut ini.

Ladang karet yang kami tuju cukup jauh, melewati ladang tetangga dan hutan lebat. Suara burung berkicau memenuhi langit-langit hutan. Satu-dua tupai terlihat melesat di batang dan cabang pepohonan. Juga burung-burung besar yang terbang rendah. Kakiku kotor sejak tadi. Sandal jepit yang licin sudah kulepas. Tanpa alas kaki melewati jalan setapak lebih mudah. (T.a/002/69.4).

Data 002 menunjukkan bahwa dengan menggunakan sistem indera pendengaran, Amelia mendengarkan dengan jelas irama alunan kicauan burung. Dengan indera penglihatan, Amelia antusias melihat gerakan tupai dan burung-burung. Dengan indera peraba, kaki Amelia menikmati tekstur tanah yang mudah dilewati. Dengan menggunakan sistem indera, manusia seakan menyatu dengan alam dan tercipta harmoni.

Dari data-data tersebut menyebutkan secara eksplisit bahwa dengan menikmati pemandangan dan nuansa alam yang menyejukkan maka akan timbul hasrat mencintai, menghormati dan seakan menyatu dengan alam. Pitoyo (2008:15) memaknai kearifan lingkungan sebagai bentuk kemauan untuk melihat, merasakan, menggagas, dan kemudian patuh terhadap norma-norma; bentuk kemauan untuk melihat dan bertindak sesuai alur hukum alam Sang Pencipta; dan bentuk kesadaran untuk menjadi bagian dari alam sehingga tercipta satu kesatuan harmoni.

\section{Rasa kepemilikan bersama}

Rasa memiliki yang eksklusif bagi komunitas atas suatu kawasan atau jenis sumber daya alam tertentu sebagai hak memiliki ini mengikat semua warga 
untuk menjaga dan mengamankan sumberdaya bersama ini dari pihak luar. Ikatan emosional yang menyatukan masyarakat untuk melestarikan dan menjaga sumberdaya alam terutama ancaman dari luar yang menyebabkan kerusakan lingkungan. Seperti pernyataan masyarakat di kampung Eliana dalam novel Eliana Serial Anak-anak Mamak. Sebagaimana kutipan berikut.

"Baiklah... menurut orangtua ini, tambang pasir itu hanya bermanfaat bagi orang kota saja. Tidak ada manfaatnya bagi kita. Karena manfaatnya hanya pada mereka, maka mereka seharusnya mengeduk pasir di kota sana, jangan menjajah kampung orang macam Kompeni dulu yang mengambil tanah penduduk. Mereka seharusnya pergi." (T.e/003/467.4).

Data 003 merupakan pernyataan Bakwo Dar yang merupakan salah satu warga masyarakat kampung bukit barisan, usianya sudah tua dan masa kecilnya masih sempat merasakan jaman penjahahan Belanda. Bakwo Dar jelasjelas menolak adanya eksploitasi sumber daya alam di daerahnya, dan menganggap hal tersebut tidak ubahnya seperti penjajahan Kompeni terhadap rakyat jelata.

"Kau tanya pendapatku, hah?" Wak Lihan berseru ketus, "Aku harus izin pada mereka untuk melintasi delta pasir setiap hendak ke ladang jagung. Sembilan tahun ladang jagung itu milikku. Genap Sembilan bulan pun tidak mereka ada di sana, tapi bertingkah sudah macam tanah milik moyang mereka. Omong kosong apa itu?" (T.e/004/467/8).

Data 004 adalah pendapat Wak Lihan yang juga masyarakat kampung bukit barisan. Wak Lihan secara tegas menyatakan penolakan terhadap adanya pengerukan pasir di daerah delta sungai karena dia memiliki ladang jagung yang terdampak wilayah penambangan pasir. Secara langsung itu telah mengganggu aktivitas Wak Lihan yang sehari-hari bekerja di ladangnya, apalagi diributkan dengan meminta izin untuk melintas di daerahnya sendiri.

"Tidak ada lagi mancing kucur, Nak. Percuma. Entah pergi ke mana ikan-ikan itu sekarang." Bapak Raju, si Pemancing Ikan Malam-malam nomor satu di kampung menggeleng prihatin, "Boleh jadi ikan-ikan pergi karena sebab lain. Tetapi suara genset listrik mereka terdengar hingga ratusan meter malammalam. Mereka sekarang juga baru berhenti mengeduk pasir lepas Isya, seperti tidak cukup waktu siang untuk bekerja. Mungkin karena itulah ikan-ikan pergi." (T.e/005/468.3).

Data 005 ini pernyataan dari Bapak Raju, warga kampung bukit barisan yang pekerjaannya mancing kucur. Mancing kucur yaitu memancing ikan pada malam hari dengan umpan yang baunya sangat khas menusuk hidung. Bapak Raju menolak sekaligus cemas karena hasil pancingannya berkurang drastis sejak adanya pengerukan pasir di daerah sekitar sungai.

Dari data-data tersebut menunjukkan bahwa masyarakat di kampung bukit barisan secara tegas dan kompak menyatakan penolakan terhadap aktivitas penambangan pasir di daerah tersebut.

$\begin{aligned} & \text { Sistem pengetahuan } \\ & \text { setempat. } \\ & \text { System } \\ & \text { ini }\end{aligned}$ memberikan kemampuan kepada masyarakat untuk memecahkan masalah-masalah yang mereka hadapi dalam memanfaatkan sumber daya alam yang terbatas. Dalam hal ini factor ilmu pengetahuan yang mempengaruhi masyarakat untuk memberikan solusi terbaik dalam setiap permasalahan. Seperti halnya gagasan Pak Bin, seorang guru dalam novel Amelia Serial Anak-anak Mamak sebagai berikut.

"Bapak akan berikan sebuah ilustrasi, perhitungan sederhana. Rata-rata satu hectare kebun karet di kampung kita 
hanya menghasilkan 1 ton getah karet setiap tahun. Bandingkan dengan petani di luar yang lebih paham, mereka bisa menghasilkan 3-4 ton getah karet setiap hektarenya selama setahun. Apa yang terjadi? Karena orang tua kita tidak tahu mana bibit karet yang baik, banyak getahnya, anti hama, dan mudah dirawat. Petani kita hanya memungut biji karet yang jatuh, kemudian menyemainya. Lantas, pohon karet yang tumbuh dari biji karet tersebut ditanam di ladang. Berpuluh tahun, petani kita hanya mewarisi pohon karet yang tidak banyak getahnya. Di perkebunan maju, bibit terbaik diperoleh dari proses mencangkok. Besok lusa akan Bapak ajarkan bagaimana cara mencangkok. Maka hasilnya lebih banyak. Orang tua kalian menghadapi situasi ini sejak berpuluh tahun lalu. Getah pohon karet yang mereka tanam keluar hanya sedikit, bahkan tidak keluar sama sekali berharihari." (T.a/006/81.1).

Data diatas merupakan perkataan Pak Bin kepada murid-muridnya mengenai kondisi sumberdaya alam mereka dengan perbandingan hasil sumberdaya alam yang menggunakan ilmu pengetahuan. Pak Bin selalu mendorong dan menginspirasi muridmuridnya termasuk Amelia untuk mencintai dan mengembangkan ilmu pengetahuan. Dengan ilmu pengetahuan, diharapkan terjadi peningkatan sumberdaya alam dan dapat memecahkan masalah-masalah.

Masalah memang selalu meliputi seseorang. Namun, manusia memiliki akal untuk berfikir dan menyerap pengetahuan dari berbagai sumber sehingga dapat dimanfaatkan untuk mengatasi permasalahan pada masyarakatnya. Hal serupa juga terdapat pada tokoh Amelia yang memberikan sumbangsih pengetahuan yang didapatkan untuk masyarakatnya pada novel Amelia Serial Anak-anak Mamak sebagaimana berikut.
"Amel sudah menemukan induk pohon kopi terbaik, Mang. Buahnya lebat dan besar, batangnya kokoh, dahannya panjang dan merata, daunnya lebar, sehat tidak pecah. Menurut Paman Unus, kita bisa menyemai biji kopi ini menjadi bibit." Aku berkata mantap. (T.a/007/299.3).

Data 007 merupakan perkataan Amelia di depan tokoh masyarakat ketika diajak pamannya mengikuti musyawarah kampung. Amelia menggunakan pemikirannya untuk menggabungkan antara inspirasi dari Pak Bin dengan pengalaman dari Paman Unus sehingga menciptakan pengetahuan untuk solusi dari permasalahan kampung mengenai hasil panen yang mengecewakan.

"Kita bisa memulainya dari ladang tidak produktif, wak. Ladang milik pak Bahar misalnya, yang hendak dijual. Itu bisa dijadikan ladang percobaan." Aku menjawab tangkas. (T.a/008/300.3).

Data 008 merupakan jawaban dari Amelia terhadap keraguan salah satu warga yang kebingungan menerapkan ide dari Amelia. Amelia menyerap informasi dengan baik lalu mengaplikasikan dengan seksama sehingga menghasilkan pengetahuan yang bermanfaat bagi orang lain.

"Kami petik dari batang kopi di tangah hutan." Aku menjawab pertanyaan Norris. "Pohonnya baik sekali. Buahnya lebat. Itu bisa menjadi induk yang baik. Kita akan menyemai semua buah dari pohon itu. Pak Bin memberikan izin belakang sekolah dijadikan tempat penyemaian. Aku membutuhkan bantuan kalian. Ini lebih serius dibanding proyek mencangkok pohon manga. Paman Unus akan membantu langsung melakukan penyemaian. Apakah kalian juga mau membantuku?" (T.a/009/306.11).

Menerapkan pengetahuan merupakan inti dari data 009. Amelia dengan diplomasi ke teman-temannya mulai berusaha mewujudkan gagasan dari Pak Bin dan mempraktekkan pengalaman 
dan pengetahuan yang di dapatkan dari Paman Unus.

Semua itu dilakukan untuk memecahkan sebuah permasalahan masyarakat kampung bukit barisan mengenai panen kopi dengan hasil yang kurang memuaskan. Dengan mengembangkan suatu pengetahuan, seseorang akan mampu memecahkan masalah yang terjadi dalam masyarakatnya meskipun sumberdaya alamnya terbatas.

\section{Teknologi tepat guna dan hemat.}

Masyarakat memiliki daya adaptasi dalam penggunaan teknologi sederhana yang tepat guna dan hemat energy sesuai dengan kondisi alam setempat. Disinilah peranan kekreatifan masyarakat dibutuhkan. Untuk memenuhi kebutuhannya namun sarana dan prasarana tidak mencukupi maka perlu adanya teknologi sederhana namun berguna. Seperti yang ditampilkan masyarakat di lembah bukit barisan pada novel Amelia Serial Anak-anak Mamak. Kutipannya sebagai berikut.

Anak-anak berlari di atas tanah hitam gosong. Orang-orang berbaris memegang kayu panjang yang ditusukkan ke tanah. Di belakangnya menyusul orang-orang yang membawa mangkok berisi padi, membungkuk, benih dimasukkan ke lubang tersebut, ditutup dengan tanah gembur. Barisan itu mulai maju sesuai garis tali raffia dengan kecepatan teratur, benih padi mulai disebar. (T.a/010/8.4).

Data diatas diketahui bahwa masyarakat kampung bukit barisan menggunakan teknologi sangat sederhana ketika tani. Mereka menggunakan kayu yang sudah ditentukan kelancipan ujungnya dan mereka juga menggunakan tali raffia untuk mengatur jarak. Sungguh teknologi pada jaman itu sangat sederhana namun tepat guna dan sesuai dengan kondisi alam.

Tumpukan kayu bakar itu diambil Mamak dari ladang karet. Banyak cabang pohon karet yang mati lantas patah, jatuh. Cabang dengan ukuran sebetis orang dewasa itu kemudian dipotong dan dibelah dengan panjang 50-60 sentimeter. Zaman itu, semua rumah di kampung menggunakan tungku kayu bakar, tidak ada kompor minyak tanah. Kayu bakar ditumpuk rapi di penyimpanan sementara, dibawah pondok kecil belakang rumah, agar tetap kering dan siap digunakan setiap saat. (T.a/011/45.5).

Data diatas menunjukkan bahwa masyarakat kampung bukit barisan menggunakan teknologi sangat sederhana ketika memasak. Mereka menggunakan kayu bakar dan dengan segala tekniknya untuk tetap menyala apinya. Pada jaman itu masyarakat belum ada kompor minyak tanah, apalagi kompor gas. Jadi, mereka memanfaatkan teknologi yang sesuai dengan kondisi.

Setiap masyarakat berbeda dalam hal teknologinya dan salah satunya adalah factor kondisi alam. Hal ini dapat ditemukan pada kebiasaan Bakwo Dar pada novel Burlian Serial Anak-anak Mamak sebagaimana kutipan berikut.

Sungai yang membatasi bagian bawah kebun itu tipikal sungai hutan. Sungainya kecil, lebarnya paling dua meter dan dalamnya rata-rata satu meter. Air sungainya mengalir jernih di balik tumpukan daun jatuh. Bubu bambu itu diletakkan beberapa hari lalu dan selalu saja ada ikan yang tertangkap. (T.b/012/75.2).

Dari data diatas diketahui bahwa masyarakat kampung bukit barisan teknologi yang digunakan untuk menangkap ikan cukup sederhana yakni menggunakan bubu ikan. Bubu ikan yaitu perangkap ikan yang terbuat dari anyaman bilah bambu, ukuran dan bentuknya seperti bantal guling. Bubu diletakkan di sungai dengan pintu jebakan menghadap ke hilir untuk menjebak ikan-ikan yang berenang berhuluan. 
Selain teknologi menangkap ikan, juga ada teknologi sederhana untuk memotong kayu. Seperti kutipan pada novel Pukat sebagai berikut.

"Biar kalian bisa bergantian memakainya." Bapak menyeringai. Belincong itu semacam kapak bermata satu, dengan tungkai kayu sepanjang satu meter. Peralatan lazim untuk menebang pohon besar. Kalian harus mencengkram kokoh tungkainya dengan kedua tangan, lantas menghantamkan mata kapaknya. (T.p/013/286.6)

Dari data diatas dapat diketahui bahwa Bapak memberikan belincong ke Burlian dan Pukat. Belincong tersebut digunakan mereka untuk menebang pohon besar. Pohon besar ditebang untuk membuka lahan yang kurang produktif. Dengan menggunakan belincong pada saat itu tergolong teknologi yang tepat guna.

\section{Sistem penegakan aturan-aturan adat.}

Sistem ini memiliki alokasi dan penerapan aturan-aturan adat yang bisa mengamankan sumberdaya milik bersama dari penggunaan berlebihan, baik oleh masyarakat sendiri maupun oleh masyarakat luar (pendatang). Dalam hal ini masyarakat tradisional sudah memiliki pranata dan hokum adat yang mengatur semua aspek kehidupan bermasyarakat dalam suatu kesatuan sosial tertentu. Hal serupa juga terjadi pada percakapan Mang Unus bersama Burlian dan Pukat pada novel Burlian Serial Anak-anak Mamak seperti kutipan dibawah ini.

"Hanya sebagian orang tua kampung yang tahu kalau ini habitat mereka, Burlian." Mang Unus memimpin perjalanan kembali, berhiliran ke jebakan bilah-bilah bambu. "Dan mereka memutuskan untuk melindunginya dari remaja-remaja tanggung yang serba ingin tahu, orang dewasa yang nekad, atau pemburu liar dari kota dengan menceritakan kisah-kisah seram itu." (T.b/014/259.6).

"Itu kebijakan alam yang paling asli, Burlian, Pukat. Meski caranya sederhana, sejak aku dan Bapak kau seumuran kalian melihat pertama kalinya, hingga hari ini rusarusa hutan itu tetap lestari. Sudah lebih empat puluh tahun tabu tentang 'sungai larangan' efektif melindunginya. Entahlah besok-lusa, siapa yang tahu. Ah semakin lama, semakin banyak saja pemburu dari kota yang masuk hutan, dan mulai tidak mempan dengan cerita itu." Mang Unus menghela napas pelan. (T.b/015/260.1).

"Kalau tempat tadi rahasia, kenapa Mang Unus menunjukkannya pada kami?" Kak Pukat bertanya, mengeluarkan suara setelah setengah jam terakhir hanya terdiam. (T.b/016/260.2).

"Kenapa? Karena aku yakin kalian tidak akan mengganggu rusa-rusa itu. Aku juga yakin, besok lusa kalian juga tidak akan buncah bercerita ke teman-teman di kelas soal kejadian sore ini. Kalian akan menutup mulut. menjadi bagian kebijakan tetua kampung" Mang Unus menatap takjim, kembali menyentuh bahu-bahu kami. "Burlian, Pukat, leluhur kita hidup bersisian dengan alam lebih dari ratusan tahun. Mereka hidup dari kasih sayang hutan yang memberikan segalanya. Maka sudah sepatutnyalah mereka membalas kebaikan itu dengan menjaga hutan dan seluruh isinya." (T.b/017/260.3).

Keempat data diatas merupakan data dialog antara Paman Unus dengan Burlian dan Pukat ketika mereka berdua menunggu hasil jebakannya terhadap burung. Mereka menangkap burung seperlunya, tidak berlebihan. Sementara menunggu, Paman Unus mengajak Burlian dan Pukat ke habitat Rusa Bertanduk yang terdapat di hutan tersebut. Paman Unus mengingatkan Burlian dan Pukat aturan adat mengenai kelestarian dan konservasi lingkungan.

Kebijakan alam dari masyarakat setempat untuk kemudian dijadikan aturan-aturan yang ditegakkan, meskipun ada sebagian yang tidak tertulis, namun 
hal tersebut merupakan bukti bahwa masyarakat memiliki perilaku dan tata nilai dalam berinteraksi dengan lingkungan. Sesuai dengan pernyataan Supriatna (2008:1) yang menyatakan bahwa Kearifan lingkungan merupakan tata nilai atau perilaku hidup masyarakat local dalam berinteraksi dengan lingkungan tempatnya hidup secara arif.

\section{Mekanisme pemerataan hasil panen atau sumberdaya milik bersama}

Mekanisme ini dapat mencegah munculnya kesenjangan berlebihan di dalam masyarakat tradisional. Tidak adanya kecemburuan atau kemarahan sosial akan mencegah pencurian atau penggunaan sumberdaya di luar aturan adat yang berlaku. Hal itu terjadi pada keluarga Pak Syahdan pada novel Amelia Serial Anak-anak Mamak kutipan sebagai berikut.

Ladang kopi milik bapak cukup luas.

Bapak mengajak beberapa tetangga untuk membantu panen, bergotong royong. Mamak menyiapkan bekal yang akan dibawa untuk bekerja sepanjang hari. (T.a/018/186.10).

Dari data diatas menjelaskan bahwa Pak Syahdan merupakan tokoh masyarakat dengan kehidupan yang mencukupi, mempunyai ladang pohon karet dan kopi. Dia selalu menegakkan nilai-nilai kearifan lingkungan dalam kondisi apapun, terutama ketika panen kopi. Dia selalu mengajak tetangga untuk membantu panen dan nantinya hasilnya akan dibagikan.

Dalam suatu masyarakat yang menjunjung nilai-nilai kearifan lingkungan selalu memiliki mekanisme sumberdaya milik bersama. Apabila suatu keluarga panen ataupun menebar benih maka penduduk yang lain dilibatkan. Hal tersebut ada di dalam kutipan novel Pukat sebagai berikut.

Setelah hampir tiga bulan persiapan, mulai dari membersihkan semak belukar, menebang batang pohon, membuat garis pembatas, lantas pembakaran, ladang siap digunakan. Hari ini adalah hari menebar benih. Mamak mengundang hampir seluruh penduduk kampung, sekaligus syukuran. (T.p/019/303.3).

Dari data tersebut dapat diketahui bahwa Mamak mengundang hampir seluruh penduduk untuk syukuran dan mempersiapkan menebar benih. Dengan mengundang hampir seluruh penduduknya, maka mencegah munculnya kesenjangan sosial.

\section{SIMPULAN DAN SARAN Simpulan}

Berdasarkan hasil pembahasan pada bab IV, peneliti dapat simpulkan nilai-nilai kearifan lingkungan yang terdapat dalam novel serial anak-anak mamak karya Tere Liye antara lain: Rasa hormat terhadap alam dilakukan dengan memanfaatkan panca indera untuk mendorong keselarasan hubungan manusia dengan alam sekitarnya. Kedua, Rasa kepemilikan bersama masyarakat untuk menjaga sumberdaya alam terutama ancaman dari luar yang menyebabkan kerusakan lingkungan. Ketiga, Sistem pengetahuan masyarakat setempat untuk memecahkan masalah. Keempat, Teknologi tepat guna dan hemat sesuai dengan kondisi setempat. Kelima, System penegakan aturan-aturan adat yang berlaku dalam masyarakat. Keenam, Mekanisme pemerataan hasil panen atau sumberdaya milik bersama sehingga tidak ada kecemburuan social.

\section{Saran}

Pada penelitian ini ada tiga saran yang disampaikan antara lain: bahasa pengarang yang digunakan masih ada istilah yang kurang bisa dipahami oleh para pembaca. Kedua, supaya pembaca bisa memahami novel serial ini dengan benar maka harus dibaca keempat novel tersebut agar mengerti alur cerita dan maksud yang disampaikan oleh 
pengarang. Ketiga, Untuk para peneliti selanjutnya masih banyak yang bisa dikaji dan diteliti pada novel serial ini, misalkan dari segi pendidikan dan moral anak, psikologi anak, dan nilai-nilai keagamaan dalam novel serial ini.

\section{Implikasi Teoritik}

Hasil penelitian ini dapat memberikan implikasi teoritis pada pembelajaran yaitu dapat menambah wawasan tentang cara mengkaji karya sastra, khususnya novel, menggunakan kajian ekologi sastra. Pengetahuan mengenai aspek-aspek penelitian ekologi sastra, prosedur penelitiannya, teknik pengambilan data, dan hasil penelitian dalam pembelajaran sastra.

Selain itu, hasil penelitian ini juga dapat dijadikan sebagai bahan refleksi bagi para pendidik dalam memahami nilai-nilai pendidikan lingkungan hidup yang dapat diterapkan dalam kehidupan sehari-hari. Nilai-nilai pendidikan lingkungan hidup dapat membentuk karakter anak untuk melestarikan lingkungan.

\section{DAFTAR PUSTAKA}

Aminudin. 1990. Pengembangan Penelitian Kualitatif dalam Bidang Bahasa dan Sastra. Malang: Yayasan Asih, Asah, Asuh.
Amrih, Pitoyo. 2008. Ilmu Kearifan Jawa. Yogyakarta: Pinus Book Publiser.

Garrard Greg. 2004. Ecocriticism. London and New York: Routledge.

Keraf, Sonny A. 2010. Etika Lingkungan Hidup. Jakarta: Penerbit Buku Kompas.

Liye, Tere. 2009. Burlian Serial Anakanak Mamak. Jakarta: Republika.

Liye, Tere. 2010. Pukat Serial Anak-anak Mamak. Jakarta: Republika.

Liye, Tere. 2011. Eliana Serial Anakanak Mamak. Jakarta: Republika.

Liye, Tere. 2013. Amelia Serial Anakanak Mamak. Jakarta: Republika.

Nababan. 1995. "Kearifan Tradisional dan Pelestarian Lingkungan di Indonesia". Jurnal Analisis CSIS. Tahun XXIV No. 6 Tahun 1995.

Sudikan, Setya Y. 2016. Ekologi Sastra. Lamongan: C.V. Pustaka Ilalang Group.

Supriatna, Jatna. 2008. Melestarikan Alam Indonesia. Jakarta: Yayasan Obor. 